Information Management and Business Review

Vol. 2, No. 2, pp.65-80, Feb 2011

\title{
Analysis of Long-Term Relationship between Spot and Futures prices Using Johansen's Test of
} Cointegration

\author{
Sathya Swaroop Debasish \\ Reader, P. G. Department of Business Administration \\ Utkal University, Vani Vihar, Bhubaneswar-4, Orissa, India \\ sathyaswaroop2000@yahoo.com
}

\begin{abstract}
The main objective of the study is to examine the long-term relationship between spot prices and futures prices A. The study has used daily prices (closing, opening, high and low) in both spot market and futures market for the 40 sample individual stocks drawn from six leading sectors namely, Automobiles, Banking, Cement, Gas, Oil \& Refineries, Information Technology and Pharmaceutical. The period of study is from 1st January 1997 to 31st May 2009. The study begins by testing the stationarity of the spot price series and futures price series using two econometric methods namely, Philips Perron (PP) test and Augmented Dickey-Fuller (ADF) test. The long term relationship between spot prices and futures prices is statistically tested using Johansen's test of Cointegration employing likelihood Ratio (L.R.), under the hypothesis that there exists a single cointegration equation between spot and future prices. It is found that both spot prices and futures prices for the selected companies are not stationary in the level form, but there is evidence of stationarity in the first difference form. The study finds a single long-term relationship for each of the selected companies across the six sectors. Among the selected companies in each sector, those evidencing strongest relation in respective sector are Tata Motors, Punjab National Bank, Gujrat Ambuja Cements, Bongaigaon Refineries, I-Flex and GLAXO Pharma.
\end{abstract}

Key Words: Investors, Co integration, Spot price, stationarity, hypothesis

\section{Introduction}

The Indian capital market has witnessed a major transformation and structural change from the past one decade as a result of ongoing financial sector reforms initiated by the Government of India. One of the major objectives of these reforms was to bring the Indian capital market up to a certain international standard. The onset of derivative trading has significantly altered the movement of stock prices in Indian spot market; it is yet to be proved whether the derivative products have served the purpose as claimed by the Indian regulators. Equity derivatives in India were started as a part of capital market reforms to hedge price risk resulted from greater financial integration between nations in the 1990s. These reforms were an integral part of financial sector reforms recommended by the Narasimham Committee Report on Financial System in September 1992. The reforms were aimed at enhancing, competition, transparency, and efficiency in the Indian financial market.

The Indian capital market saw the launching of index futures on June 9, 2000 on BSE and on June 12, 2000 on the NSE. A year later options on index were also introduced for trading on these exchanges. Later, stock options on individual stocks were launched in July 2001. Stock futures entered the derivative segment on these exchanges from November 2001 onwards. The advent of stock index futures has profoundly changed the nature of trading on stock exchanges. The concern over how trading in futures contracts affects the spot market for underlying assets has been an interesting subject for investors, market makers, academicians, exchanges and regulators alike. These markets offer investors flexibility in altering the composition of their portfolios and in timing their transactions. Futures markets also provide opportunities to hedge the risks involved with holding diversified equity portfolios. As a consequence, significant portion of cash market equity transactions are tied to futures and options market activity. However, it is yet to be known if the introduction of stock index futures has served the purpose claimed by the regulators. 


\section{Literature Review}

Kawaller, Koch and Koch (1987) in their study estimated the lead-lag relation between S\&P 500 index futures and S\&P 500 index using simultaneous equation model. A model was constructed to describe the dynamic intra-day price relationship between the index and futures prices. Their study attributed the stronger leading role of the futures market to the infrequent trading of component stocks. Schwarz and Laatsch (1991) also investigated the price leadership of index futures over the spot market and tested the dynamic efficiency of index futures. The study was done on the Major Market Index for the sample period 1985 to 1988. The results showed that the spot and futures market were integrated such that average mispricing leading to arbitrage was eliminated within one to seven days. Chan (1992) in a study estimated the lead-lag relation between Major Market Index and Major Market Index futures under conditions of good and bad news, different trading intensities and under varying market wide movements. ARMA models were used and it was observed that the futures market led the spot market, and this was primarily due to faster information processing by the futures market. However, under bad news it was the cash index that led over the futures market while, there was no effect on the lead-lag relation during different trading intensities. Teppo, Jukka and Vesa (1995) studied the two-way causality between the Finnish stock index futures and the stock index for a period of one year from 1989 - 1990. Granger Causality tests were applied on the daily returns due to non-availability of intra-day data. The results indicated that the futures market provided predictive information for both frequent and infrequently traded stocks while the reverse causality was found to be weak.

Brooks, Rew and Ritson (2001) in their study on the lead-lag relation between the FTSE 100 stock index futures and the FTSE 100 index developed a trading strategy based on the predictive abilities of the futures market. The study used Co-integration and Error Correction model, ARMA model and vector auto-regressive model and it showed that futures led the spot market and this was attributable to faster flow of information into futures market mainly due to lower transaction costs. It was shown that the error cointegration model predicted the correct direction of the spot returns $68.75 \%$ of the time. Ghosh (1993) also observed a similar lead-lag relationship for the U.S. market with the use of an error correction model. Frino and West (2002) in their study examined the lead-lag relationship in returns on stock index futures and the underlying stock index for the Australian market between 1992 and 1997.They found that futures returns lead index returns by twenty to twenty-five minutes and there was some evidence of feedback from the equities market to the futures market. Analysis conducted on a year-by-year basis suggested that the extent to which the futures market leads the equities market had decreased over time and the relationship between the two markets had generally strengthened. This was consistent with an increase in the level of integration between the markets.

Sah and Omkarnath (2005) examined the nature and extent of relation between NSE-50 Futures and volatility of S\&P CNX Nifty. They used Granger causality test to study relationship between volatility and futures market activity. The sample data consisted of daily closing prices of S\&P Nifty and turnover from June 12, 2000 through March 25, 2004 for near month and from June 12 through January 29, 2004 for middle month and far month contracts. Their empirical study suggested that futures market activity destabilized the underlying market. The direction of causation was bi-directional in case of near month; however, causality ran from Nifty Futures to volatility of S\&P Nifty in case of far month contract. Praveen and Sudhakar (2006) studied the price discovery mechanism in India's rapidly growing commodity futures market. Granger Causality Test was used for the study that focuses on the Indian stock and commodity market. A comparison was drawn for price discovery between the grown stock market and the growing commodity market. Their study highlighted as to how the futures market influenced the spot market and facilitates better price discovery in the spot market. The spot and/or futures market dominated the price discovery, but it appeared that a better price discovery occurred when there was a mature futures market for the commodity. Reddy and Sebastin (2008) studied the temporal relationship between the equities market and the derivatives market segments of the stock market using various methods and by identifying lead-lag relationship between the value of a representative index of the equities market and the price of a corresponding index futures contract in the derivatives market. The study observed that price innovations appeared first in the derivatives market and were then transmitted to the equities market. The dynamics of such information transport between stock market and derivatives market were studied using the information theoretic concept of entropy, which captures non-linear dynamic relationship also. Pati and Kumar (2007) in their study found a positive contemporaneous relationship between futures price volatility and volume. Their study concluded 
that time-to-maturity is not a strong determinant of futures price volatility, but the rate of information arrival proxied by volume and open interest are the important sources of volatility.

\section{Johansen's Test of Co-Integration}

Economically speaking, two types of relationship may exist between two time series: i) long term, or equilibrium and ii) short term relationship. In case of the long term relationship, a change in one variable permanently changes the equilibrium level of another variable. While, in the case of short term relationship, the impact of the change in one variable on another variable has short life and it is reversible. Statistically, the long term relationship is detected by the presence of co integration between the variable at their level form; while, short term relationship is analyzed at the differenced form. If two variables are co integrated, there exists a long term or equilibrium relationship between them. However, in the short run, there may be disequilibrium, which is corrected through the 'error correction mechanism.

The test of Cointegration identifies the long run structural relationship among the variables under consideration. In other words, it tries to establish whether in the long run the variables under study would move in the same direction or not. The current study envisages to study whether the spot market and futures market under consideration move in the same direction in the long run or not. Consider two time series $\mathrm{x}_{\mathrm{t}}$ and $\mathrm{y}_{\mathrm{t}}$, these two time series can be said to be co integrated if:

1. both time series $\left(\mathrm{x}_{\mathrm{t}}\right.$ and $\left.\mathrm{y}_{\mathrm{t}}\right)$ are I(1) .i.e., become stationary after first differencing, and

2. there is some linear combination of $x_{t}$ and $y_{t}$ which is I(0) i.e., stationary in level form

In general for two I(1) variables, any linear combination among them, would be of the form: $y_{t}=b_{0}+b_{1} x_{t}+u_{t}$, with $b_{0}$ and $b_{1}$ taking different values, to be I(1) as well. However, if $x_{t}$ and $y_{t}$ are linked together in a linear (long-term) relationship then one will find something unusual occurring, namely the second of the two conditions for the existence of co integration will hold: there will be at least one linear combination of $\mathrm{x}_{\mathrm{t}}$ and $\mathrm{y}_{\mathrm{t}}$ that will be $\mathrm{I}(0)$, that is stationary. When this is the case, one can be certain that any correlation over time between $x_{t}$ and $y_{t}$ is not spurious. When conditions (a) and (b) above hold, it is said that the time series $x_{t}$ and $\mathrm{y}_{\mathrm{t}}$ are co integrated. Thus, co integration is the statistical equivalent of the existence of a long-run economic relationship between I(1) variables. The meaning is that of existence of long-run equilibrium relationship. This co integration between $S_{t}$ and $F_{t-i}$ is a necessary condition for market efficiency (Lai and Lai, 1991). The main objective of the study is to examine the long-term relationship between spot prices and futures prices. For this purpose, the study has used Johansen's test of Cointegration

\section{Data and Sources}

The study has used daily prices (closing, opening, high and low) in both spot market and futures market for the 40 sample individual stocks drawn from six leading sectors namely, Automobiles, Banking, Cement, Gas, Oil \& Refineries, Information Technology and Pharmaceutical. The results of the 40 selected companies are presented in the section Analysis and Findings. In terms of market capitalization, the leading stocks under each of the six selected sectors were shortlisted. On the basis of complete data availability of spot prices during the study period and a minimum 24 months of continuous daily futures data, we finalized the selected 40 companies. The spot prices and the one-month futures prices of the selected stocks are taken for the study. The futures time series analyzed here uses data on the near month contract as they are most heavily traded. The study used data on daily opening, low, high and closing prices of the selected indices and individual stocks traded in the spot market. The futures data include the near-month prices of daily opening, low, high and closing. The study was entirely based on time series data from secondary sources and collected from official website of National Stock Exchange. The period of study is from $1^{\text {st }}$ January 1997 to $31^{\text {st }}$ May 2009.

\section{Methods}

Methodology directs the researcher to conduct the research in a systematic manner and deals with sampling plan and various tools to carry out the analysis on the data collected. In the first place, the daily returns based on spot and futures prices were computed. The price series consisted of open price, low, high, and closing 
prices for both spot and futures market. The returns for the futures contract and the spot index are defined as $\mathrm{RF}_{\mathrm{t}}=\left\{\mathrm{Ln}\left(\mathrm{F}_{\mathrm{t}} / \mathrm{F}_{\mathrm{t}-1}\right)\right\}$ and $\mathrm{RSt}=\left\{\mathrm{Ln}\left(\mathrm{S}_{\mathrm{t}} / \mathrm{S}_{\mathrm{t}-1}\right)\right\}$, respectively where Ft and $\mathrm{S}_{\mathrm{t}}$ are the futures prices and spot prices on day $t$, respectively.

The long term relationship between spot prices and futures prices is statistically tested using Johansen's test of Cointegration employing likelihood Ratio (L.R.), under the hypothesis that there exists a single cointegration equation between spot and future prices. Two sets of null hypotheses are tested to find out the number of co integrating relations between the spot and futures prices series. These are as given below:

1. First Null Hypothesis: $r=0$ (There exists no cointegration relationship between the spot and futures prices)

2. Second Null Hypothesis: $r \leq 1$ (There exists less than or equal to one cointegration relationship between the spot and futures prices)

Acceptance of the first hypothesis indicates that there is no conintegration relationship between spot and futures prices. If only the first null hypothesis is rejected, it implies that there exists cointegration relationship. The study assumes linear deterministic trend in the data and testing of hypothesis is done employing Likelihood Ratio (L.R.) test using Eviews software package. The null hypothesis testing is estimated for 1\% and $5 \%$ level of significance. If the first hypothesis is rejected and the second hypothesis is not rejected, we conclude that there exists one single cointegrating relation between spot prices and futures prices. Cointegration theory implies that for a vector of time series, the variables are said to be cointegrated if linear combinations are stationary without differencing, even if the individual elements of the vector need to be differenced at least once to become stationary (Johansen and Juselius,1990).

Although the two series may be non stationary, they may move closely together in the long run so that the difference between them is stationary. Two series $S_{t}$ (spot price) and $F_{t}$ (futures prices) are said to be integrated of the order one, denoted by I(1), if they become stationary after first difference. If there are two such series which are I(1) integrated and their linear combination is stationary, then these two series are said to be cointegrated. This relationship is the long run equilibrium relationship between $S_{t}$ and $F_{t}$. However, the most crucial requirement for applying the standard cointegration tests (including the most popular, the Johansen's cointegration test) is that the variables should be integrated of the same order. Before testing for cointegration, each individual price series should be examined for stationarity. Phillips-Perron (PP) unit root test and Augmented Dickey-Fuller (ADF) tests as discussed in section 3.4.3 are the common methods. If both the futures and cash price series are stationary at the same level, Johansen's cointegration tests can be conducted. Thus, the analysis begins by first testing the stationarity of price series in both spot market and futures market for the selected companies across the six sectors.

\section{Analysis and Findings}

\section{Test of Stationarity for Spot prices \& Futures prices of selected companies in Automobile sector}

The values of test of stationarity of spot and futures prices with regard to six selected Automobile companies are presented in table 1. It is observed that the spot prices and futures of all the companies excluding Bajaj Auto are not significant in the level form with respect to ADF test. Bajaj Auto showed significant stationarity (at $1 \%$ level) in level form with values of -3.1652 in spot prices and -2.351 for futures prices (with respect to $\mathrm{ADF}$ test). However, in regard to PP test the spot price series of Bajaj Auto was not found to be significant in the level form. It can be seen that the first differences in both spot and futures prices are observed to be stationary with significance at $1 \%$ level, and this is for both ADF and PP tests. 
Table-1: Results of Stationarity Tests for Spot and Futures prices for selected companies in Automobile sector

\begin{tabular}{|c|c|c|c|c|c|c|c|c|c|}
\hline \multirow[t]{3}{*}{ S.No. } & \multirow[t]{3}{*}{ Companies } & \multicolumn{4}{|c|}{ Panel-A : Spot prices } & \multicolumn{4}{|c|}{ Panel-B: Futures prices } \\
\hline & & \multicolumn{2}{|c|}{ ADF test } & \multicolumn{2}{|c|}{ PP Test } & \multicolumn{2}{|c|}{ ADF test } & \multicolumn{2}{|c|}{ PP Test } \\
\hline & & $\begin{array}{l}\text { Level } \\
\text { Form }\end{array}$ & $\begin{array}{l}\text { First } \\
\text { Difference }\end{array}$ & $\begin{array}{l}\text { Level } \\
\text { Form }\end{array}$ & $\begin{array}{l}\text { First } \\
\text { Difference }\end{array}$ & $\begin{array}{l}\text { Level } \\
\text { Form }\end{array}$ & $\begin{array}{l}\text { First } \\
\text { Difference }\end{array}$ & $\begin{array}{l}\text { Level } \\
\text { Form }\end{array}$ & $\begin{array}{l}\text { First } \\
\text { Difference }\end{array}$ \\
\hline 1 & Bajaj Auto & $-3.1652^{*}$ & $-9.652^{* *}$ & 1.715 & $-24.538^{*}$ & $-2.351^{*}$ & $-12.351^{*}$ & 1.956 & $-30.654^{*}$ \\
\hline 2 & Hero Honda & -2.685 & $-8.238 *$ & -2.355 & $-23.148^{*}$ & -2.315 & $-21.526^{*}$ & -1.523 & $-31.842^{*}$ \\
\hline 3 & Maruti Udyog & -2.756 & $-14.568^{*}$ & -2.005 & $-32.784^{*}$ & -1.977 & $-11.385^{*}$ & -1.576 & $-27.631^{*}$ \\
\hline 4 & $\mathrm{M} \& \mathrm{M}$ & -1.985 & $-13.522^{*}$ & -1.526 & $-33.647^{*}$ & -1.652 & $-10.552^{*}$ & -1.237 & $-28.468^{*}$ \\
\hline 5 & Tata Motors & -0.468 & $-15.326^{*}$ & -2.054 & $-29.781^{*}$ & -0.324 & $-19.645^{*}$ & -1.156 & $-21.348^{*}$ \\
\hline 6 & TVS Motors & -2.526 & $-12.568^{*}$ & -1.684 & $-19.525^{* *}$ & -2.112 & $-14.582^{*}$ & -2.018 & $-32.549 *$ \\
\hline
\end{tabular}

Note: $^{*}$ and ${ }^{* *}$ denote significance at $1 \%$ and $5 \%$ level, respectively.

Panel-A of table 1 provides the value of stationarity test on spot prices in level form and the first difference of spot prices. The highest ADF value for first difference is witnessed for Tata Motors (-15.326), whereas the lowest for Hero Honda (-8.238). Maximum PP value for first difference is seen for M\&M (-33.647) and minimum for TVS Motors (-19.525). Therefore, we reject the null hypothesis of 'spot price series is stationary in the level form' for all the selected Automobile companies, except Bajaj Auto. Panel-B of table 6.2 provides the value of stationarity test on futures prices in level form and the first difference of futures prices. The highest ADF value for first difference is witnessed for Hero Honda (21.526) and the lowest for M \& M (10.552). Maximum PP value for first difference is seen for TVS Motors (-32.549) and minimum for Tata Motors (-21.348). Therefore, we reject the null hypothesis of 'futures price series is stationary in the level form' for all the selected automobile companies, except Bajaj Auto. Thus, both spot and futures prices on the selected Automobile companies are found to be stationary only in the first difference form and not in the level form. Only with respect to ADF test, Bajaj Auto is evidenced to be stationary in level form for both spot and futures price series.

\section{Test of Stationarity for Spot prices \& Futures prices of selected companies in banking sector}

The table 2 presents the values of test of stationarity of spot and futures prices with regard to selected nine banks. The ADF and PP values for spot prices in level form are not found to be statistically significant for all the nine banks. It can be observed that the spot prices (panel-A) of all these banks are significant (at 1\% level) in the first difference form with respect to both ADF test and PP test. Highest ADF value for first difference form is witnessed for PNB (-16.328), while lowest value is observed for IDBI (-10.358). Maximum PP value for first difference form is seen for Union Bank of India (-45.679) and minimum for Bank of Baroda (-29.152). Therefore, we reject the null hypothesis of 'spot price series is stationary in the level form' for all the nine banks. Panel-B of table 2 provides the value of stationarity test on futures prices in level form and the first difference form of futures prices. It can be seen that the futures prices of the selected nine banks are found to be non-stationary in the level form, but are stationary in the first difference form with respect to both ADF test and PP test. Highest ADF value for first difference form in futures prices series is witnessed for Oriental Bank (-18.649), while lowest is for HDFC Bank ( -9.378). Maximum PP value for first difference in futures prices is seen for ICICI Bank (-32.364) and minimum for SBI(-5.649). Therefore, we reject the null hypothesis of 'futures price series is stationary in the level form' for the selected nine stocks in the Banking sector, and the alternative hypothesis will be accepted. Thus, both spot and futures prices on the nine selected banks are found to be stationary only in the first difference form and not in the level form. 
Table-2: Results of Stationarity Tests for Spot and Futures prices for selected companies in Banking sector

\begin{tabular}{|c|c|c|c|c|c|c|c|c|c|}
\hline \multirow[t]{3}{*}{ S.No. } & \multirow[t]{3}{*}{ Companies } & \multicolumn{4}{|c|}{ Panel-A : Spot prices } & \multicolumn{4}{|c|}{ Panel-B: Futures prices } \\
\hline & & \multicolumn{2}{|c|}{ ADF test } & \multicolumn{2}{|c|}{ PP Test } & \multicolumn{2}{|c|}{ ADF test } & \multicolumn{2}{|c|}{ PP Test } \\
\hline & & $\begin{array}{l}\text { Level } \\
\text { Form }\end{array}$ & $\begin{array}{l}\text { First } \\
\text { Difference }\end{array}$ & $\begin{array}{l}\text { Level } \\
\text { Form }\end{array}$ & $\begin{array}{l}\text { First } \\
\text { Difference }\end{array}$ & $\begin{array}{l}\text { Level } \\
\text { Form }\end{array}$ & $\begin{array}{l}\text { First } \\
\text { Difference }\end{array}$ & $\begin{array}{l}\text { Level } \\
\text { Form }\end{array}$ & $\begin{array}{l}\text { First } \\
\text { Difference }\end{array}$ \\
\hline 1 & Bank of Baroda & -1.440 & $-13.542^{*}$ & -1.865 & $-29.152^{*}$ & -1.465 & $-14.356^{*}$ & -2.346 & $-29.134^{*}$ \\
\hline 2 & Canara bank & -2.123 & $-15.342^{*}$ & -1.205 & $-30.643^{*}$ & -1.348 & $-13.485^{*}$ & -1.798 & $-31.164^{*}$ \\
\hline 3 & HDFC Bank & -1.526 & $-14.523^{*}$ & -1.523 & $-30.762 *$ & -1.679 & $-9.378^{*}$ & -2.346 & $-31.461^{*}$ \\
\hline 4 & ICICI Bank & -1.002 & $-12.348^{*}$ & -2.543 & $-31.542 *$ & -2.013 & $-12.347^{*}$ & -3.461 & $-32.364^{*}$ \\
\hline 5 & IDBI & -2.541 & $-10.358^{*}$ & -2.334 & $-35.228^{*}$ & -2.146 & $-11.376^{*}$ & -3.115 & $-31.061^{*}$ \\
\hline 6 & Oriental Bank & -1.521 & $-14.526^{*}$ & -2.076 & $-31.689 *$ & -1.986 & $-18.649 *$ & -2.461 & $-30.785^{*}$ \\
\hline 7 & PNB & -1.446 & $-16.328^{*}$ & -0.986 & $-30.465^{*}$ & -1.463 & $-12.347^{* *}$ & -3.105 & $-31.221^{*}$ \\
\hline 8 & SBI & -2.643 & $-12.357^{*}$ & -3.125 & $-38.462 *$ & -2.113 & $-14.338^{*}$ & -2.113 & $-25.649^{*}$ \\
\hline 9 & $\begin{array}{l}\text { Union Bank of } \\
\text { India }\end{array}$ & -2.943 & $-11.846^{*}$ & -2.781 & $-45.679 *$ & -2.461 & $-10.684^{*}$ & -1.996 & $-30.641^{*}$ \\
\hline
\end{tabular}

\section{Test of Stationarity for Spot prices \& Futures prices of selected companies in Cement sector}

The values of the test of Stationarity of spot and futures prices with regard to selected Cement companies are presented in table 3. It is observed that the spot prices and futures prices of all these companies excluding India Cements are not significant in the level form with respect to ADF test. India Cements showed significant stationarity (at 1\% level) in level form with values of -4.463 in spot prices and -3.931 for futures prices (with respect to ADF test). However, in regard to PP test India Cements was not found significant in the level form for either the spot prices or the futures prices series.

Table-3: Results of Stationarity Tests for Spot and Futures for selected companies in Cement sector

S.No. Companies Panel-A : Spot prices

ADF test

Level

Form
PP Test

First Level Difference Form
First

Difference Form
Panel-B: Futures prices

ADF test PP Test

First Level First Difference Form Difference

\begin{tabular}{|c|c|c|c|c|c|c|c|c|c|}
\hline 1 & ACC & -1.546 & $-13.401^{*}$ & -1.519 & $-22.613^{*}$ & -1.665 & $-13.461^{*}$ & -1.611 & $-29.641^{*}$ \\
\hline 2 & Grasim Cements & -2.276 & $-7.613^{*}$ & -2.067 & $-18.964 *$ & -2.253 & $-7.643^{*}$ & -2.054 & $-19.463^{*}$ \\
\hline 3 & $\begin{array}{l}\text { Gujrat Ambuja } \\
\text { Cements }\end{array}$ & 0.443 & $-9.279 *$ & 0.461 & $-23.461^{*}$ & 0.461 & $-9.166^{*}$ & 0.461 & $-18.457^{*}$ \\
\hline 4 & India Cements & $-4.463^{*}$ & $-9.331 *$ & -2.176 & $-19.647^{*}$ & $-3.931 *$ & $-9.984 *$ & -2.113 & $-20.341^{*}$ \\
\hline
\end{tabular}

It can be seen that the first differences in both spot and futures prices for the selected Cement companies are observed to be stationary with significance at $1 \%$ level, and this is for both ADF and PP tests except for India cements. Panel-A of table 6.4 provides the value of stationarity test on spot prices in level form and the first difference of spot prices. Highest ADF value for first difference form is witnessed for ACC ( -13.401), while lowest values is for Grasim Cements (-7.613). Maximum PP test value for first difference form in spot prices is 
seen for Gujrat Ambuja Cements (-23.461) and minimum for Grasim Cements (-18.964). Therefore, we reject the null hypothesis of 'spot price series is stationary in the level form' for all the selected Cement companies, except India Cements. Panel-B of table 3 provides the value of stationarity test on futures prices in level form and the first difference form of futures prices of Cement companies. Highest ADF value for first difference form is observed for ACC (-13.461) , while lowest ADF value is found for Grasim Cements (-7.643). Maximum PP test value for first difference form is evidenced for ACC (-29.641) and minimum is for Gujrat Ambuja Cements (-18.457). Therefore, we reject the null hypothesis of 'futures price series is stationary in the level form' for all the selected Cement companies, except India cements. Thus, both spot and futures prices on the selected Cement companies (except India Cements) are found to be stationary only in the first difference form and not in the level form.

\section{Test of Stationarity for Spot prices \& Futures prices of selected companies in Gas, Oil \& Refineries sector}

The table-4 presents the values of test of stationarity of spot and futures prices with regard to selected eight companies in Gas, Oil \& Refineries sector. The ADF and PP values for spot prices in level form are not found to be statistically significant for all the selected companies in this sector. It can be observed that the spot prices (panel-A) of all these companies are significant (at 1\% level) in the first difference form with respect to both ADF test and PP test. Highest ADF value for first difference form is witnessed for ONGC (-15.687), while lowest is for Bongaigaon Refineries (-10.364). Maximum PP value for first difference form in spot prices is seen for GAIL (-32.418) and minimum for HPCL (-26.643). Therefore, we reject the null hypothesis of 'spot price series is stationary in the level form' for all the eight companies in Gas, Oil \& Refineries sector.

Table-4: Results of Stationarity Tests for Spot and Futures for selected companies in Gas, Oil \& Refineries sector

\begin{tabular}{|c|c|c|c|c|c|c|c|c|c|}
\hline \multirow{3}{*}{\multicolumn{2}{|c|}{ S.No. Companies }} & \multicolumn{4}{|c|}{ Panel-A : Spot prices } & \multicolumn{4}{|c|}{ Panel-B: Futures prices } \\
\hline & & \multicolumn{2}{|c|}{ ADF test } & \multicolumn{2}{|c|}{ PP Test } & \multicolumn{2}{|c|}{ ADF test } & \multicolumn{2}{|c|}{ PP Test } \\
\hline & & $\begin{array}{l}\text { Level } \\
\text { Form }\end{array}$ & $\begin{array}{l}\text { First } \\
\text { Difference }\end{array}$ & $\begin{array}{l}\text { Level } \\
\text { Form }\end{array}$ & $\begin{array}{l}\text { First } \\
\text { Difference }\end{array}$ & $\begin{array}{l}\text { Level } \\
\text { Form }\end{array}$ & $\begin{array}{l}\text { First } \\
\text { Difference }\end{array}$ & $\begin{array}{l}\text { Level } \\
\text { Form }\end{array}$ & $\begin{array}{l}\text { First } \\
\text { Difference }\end{array}$ \\
\hline 1 & BPCL & -2.946 & $-13.845^{*}$ & -3.145 & $-30.154^{*}$ & -2.974 & $-13.946^{*}$ & -3.193 & $-33.562^{*}$ \\
\hline 2 & $\begin{array}{l}\text { Bongaigaon } \\
\text { Refineries }\end{array}$ & -1.761 & $-10.364^{*}$ & -1.802 & $-27.651^{*}$ & -1.803 & $-12.364^{*}$ & -1.826 & $-24.396^{*}$ \\
\hline 3 & GAIL & -2.241 & -15.364 & -2.243 & $-32.418^{*}$ & -2.293 & $-14.382 *$ & -2.286 & $-31.254^{*}$ \\
\hline 4 & HPCL & -2.034 & $-14.321^{*}$ & -2.076 & $-26.643^{*}$ & -3.046 & $-14.536^{*}$ & -2.104 & $-27.698^{*}$ \\
\hline 5 & IOC & -1.556 & $-14.028^{*}$ & -1.562 & $-29.846^{*}$ & -1.576 & $-13.671^{*}$ & -1.523 & $-26.125^{*}$ \\
\hline 6 & IPCL & -1.350 & $-13.942^{*}$ & -1.227 & $-30.418^{*}$ & -1.146 & $-11.885^{*}$ & -1.328 & $-31.284^{*}$ \\
\hline 7 & ONGC & -1.528 & $-15.687^{*}$ & -1.825 & $-31.543^{*}$ & -1.197 & $-14.682 *$ & -1.796 & $-31.861^{*}$ \\
\hline 8 & $\begin{array}{l}\text { Reliance } \\
\text { Industries }\end{array}$ & -2.287 & $-13.671^{*}$ & -1.513 & $-28.649 *$ & -1.663 & $-16.649 *$ & -1.158 & $-29.863^{*}$ \\
\hline
\end{tabular}

Note: ${ }^{*}$ and ${ }^{* *}$ denote significance at $1 \%$ and $5 \%$ level, respectively.

The panel-B of table 4 provides the value of stationarity test on futures prices in level form and the first difference of futures prices. It can be seen that the futures prices of the selected companies are found to be non-stationary in the level form, but are stationary in the first difference form with respect to both ADF test and PP test. Highest ADF value for first difference in futures prices series is witnessed for Reliance Industries $(-16.649)$, whereas, lowest value is found for IPCL (-11.885). Maximum PP test value for first difference in futures prices is seen for BPCL (-33.562) and minimum for IOC (-26.125). Therefore, we reject the null hypothesis of 'futures price series is stationary in the level form' for the all the selected companies. Thus, both spot and futures prices on the eight companies in the Gas, Oil \& Refineries sector are found to be stationary only in the first difference form and not in the level form. 


\section{Test of Stationarity for Spot prices \& Futures prices of selected companies in Information Technology (IT) sector}

The values of test of stationarity (ADF and PP test) of spot and futures prices with regard to selected IT companies are provided in table 5. The ADF and PP values for spot prices in level form are not found to be statistically significant for all the seven IT companies. It is seen that the spot prices (panel-A) of all the selected IT Companies are significant (at 1\% level) in the first difference form with respect to both ADF test and PP test. Highest ADF value for first difference form is witnessed for Patni Computer (-15.292), while lowest is for Satyam Computers (-9.774). Maximum PP value for first difference form in spot prices is seen for I-Flex (-31.462) and minimum for WIPRO (-24.653). Therefore, we reject the null hypothesis of 'spot price series is stationary in the level form' for all the seven IT companies.

Table-5: Results of Stationarity Tests for Spot and Futures for selected companies in Information Technology (IT) sector

\begin{tabular}{|c|c|c|c|c|c|c|c|c|c|}
\hline \multirow[t]{3}{*}{ S.No. } & \multirow[t]{3}{*}{ Companies } & \multicolumn{4}{|c|}{ Panel-A : Spot prices } & \multicolumn{4}{|c|}{ Panel-B: Futures prices } \\
\hline & & \multicolumn{2}{|c|}{ ADF test } & \multicolumn{2}{|c|}{ PP Test } & \multicolumn{2}{|c|}{ ADF test } & \multicolumn{2}{|c|}{ PP Test } \\
\hline & & $\begin{array}{l}\text { Level } \\
\text { Form }\end{array}$ & $\begin{array}{l}\text { First } \\
\text { Difference }\end{array}$ & $\begin{array}{l}\text { Level } \\
\text { Form }\end{array}$ & $\begin{array}{l}\text { First } \\
\text { Difference }\end{array}$ & $\begin{array}{l}\text { Level } \\
\text { Form }\end{array}$ & $\begin{array}{l}\text { First } \\
\text { Difference }\end{array}$ & $\begin{array}{l}\text { Level } \\
\text { Form }\end{array}$ & $\begin{array}{l}\text { First } \\
\text { Difference }\end{array}$ \\
\hline 1 & I-Flex & -0.996 & $-14.652 *$ & -1.003 & $-31.462 *$ & -1.035 & $-13.382 *$ & -1.320 & $-31.525^{*}$ \\
\hline 2 & Infosys Tech & -0.864 & $-12.376^{*}$ & -0.965 & $-30.671^{*}$ & -0.964 & $-12.364^{*}$ & -0.865 & $-32.481^{*}$ \\
\hline 3 & $\begin{array}{l}\text { Patni } \\
\text { Computers }\end{array}$ & -0.564 & $-15.292^{*}$ & -0.554 & $-29.648^{*}$ & -0.569 & $-13.742^{*}$ & -0.536 & $-24.641 *$ \\
\hline 4 & Polaris & -2.561 & $-12.384^{*}$ & -2.143 & $-30.258^{*}$ & -2.413 & $-8.285^{*}$ & -2.476 & $-29.643^{*}$ \\
\hline 5 & $\begin{array}{l}\text { Satyam } \\
\text { Computers }\end{array}$ & 1.286 & $-9.774^{*}$ & 1.176 & $-26.384^{*}$ & 1.286 & $-9.641^{*}$ & 1.135 & $-20.384^{*}$ \\
\hline 6 & TCS & -2.461 & $-13.218^{*}$ & -2.346 & $-30.682^{*}$ & -2.346 & $-14.213^{*}$ & -2.315 & $-30.136^{*}$ \\
\hline 7 & WIPRO & -1.886 & $-10.384^{*}$ & -2.006 & $-24.653^{*}$ & -1.826 & $-11.025^{*}$ & -1.965 & $-25.355^{*}$ \\
\hline
\end{tabular}

Note: ${ }^{*}$ and ${ }^{* *}$ denote significance at $1 \%$ and $5 \%$ level, respectively.

Panel-B of table 5 provides the value of stationarity test on futures prices in level form and the first difference form of futures prices series. It is observed that the futures prices of the selected companies are found to be non-stationary in the level form, but are stationary in the first difference form with respect to both ADF test and PP test. Highest ADF value for first difference in futures prices series is witnessed for TCS (-14.213), while lowest for Polaris (-8.285). Maximum PP test value for first difference in futures prices is seen for Infosys Tech (-32.481) and minimum for Patni Computers (-24.641). Therefore, we reject the null hypothesis of 'futures price series is stationary in the level form' for the IT companies. Thus, both spot and futures prices on the selected seven IT companies are found to be stationary only in the first difference form and not in the level form.

Test of Stationarity for Spot prices \& Futures prices of selected companies in Pharmaceutical Sector The table 6 presents the values of test of stationarity of spot and futures prices with regard to selected six companies in Pharmaceutical sector. The ADF and PP values for spot prices in level form are not found to be statistically significant for all these Pharmaceutical companies. It can be observed that the spot prices (panelA) of all the selected Pharmaceutical companies are significant (at 1\% level) in the first difference form with respect to both ADF test and PP test. Highest ADF value for first difference form is witnessed for Ranbaxy (16.328), while lowest is for Dr. Reddy's (-10.286). Maximum PP value for first difference form is seen for Wockhardt (-33.619) and minimum is evidenced for DABUR (-23.643). Therefore, we reject the null hypothesis of 'spot price series is stationary in the level form' for all the six Pharmaceutical companies. 
Table-6: Results of Stationarity Tests for Spot and Futures for selected companies in Pharmaceutical Sector

\begin{tabular}{|c|c|c|c|c|c|c|c|c|c|}
\hline \multirow[t]{3}{*}{ S.No. } & \multirow[t]{3}{*}{ Companies } & \multicolumn{4}{|c|}{ Panel-A : Spot prices } & \multicolumn{4}{|c|}{ Panel-B: Futures prices } \\
\hline & & \multicolumn{2}{|c|}{ ADF test } & \multicolumn{2}{|c|}{ PP Test } & \multicolumn{2}{|c|}{ ADF test } & \multicolumn{2}{|c|}{ PP Test } \\
\hline & & $\begin{array}{l}\text { Level } \\
\text { Form }\end{array}$ & $\begin{array}{l}\text { First } \\
\text { Difference }\end{array}$ & $\begin{array}{l}\text { Level } \\
\text { Form }\end{array}$ & $\begin{array}{l}\text { First } \\
\text { Difference }\end{array}$ & $\begin{array}{l}\text { Level } \\
\text { Form }\end{array}$ & $\begin{array}{l}\text { First } \\
\text { Difference }\end{array}$ & $\begin{array}{l}\text { Level } \\
\text { Form }\end{array}$ & $\begin{array}{l}\text { First } \\
\text { Difference }\end{array}$ \\
\hline 1 & CIPLA & -2.413 & $-13.561^{*}$ & -2.337 & $-30.642^{*}$ & -2.402 & $-13.256^{*}$ & -2.338 & $-33.518^{*}$ \\
\hline 2 & Dr. Reddy's & -1.882 & $-10.286^{*}$ & -1.962 & $-24.386^{*}$ & -1.883 & $-11.283^{*}$ & -1.986 & $-27.382^{*}$ \\
\hline 3 & DABUR & -1.632 & $-15.368^{*}$ & -2.061 & $-23.643^{*}$ & -1.956 & $-14.397^{*}$ & -1.923 & $-30.169 *$ \\
\hline 4 & $\begin{array}{l}\text { GLAXO } \\
\text { Pharma }\end{array}$ & -2.135 & $-12.386^{*}$ & -1.536 & $-28.617^{*}$ & -2.116 & $-16.347^{*}$ & -2.036 & $-28.643^{*}$ \\
\hline 5 & Ranbaxy & -1.523 & $-16.279 *$ & -1.452 & $-30.118^{*}$ & -1.561 & $-14.382^{*}$ & -1.568 & $-25.114^{*}$ \\
\hline 6 & Wockhardt & -1.468 & $-13.256^{*}$ & -0.998 & $-33.619 *$ & -1.436 & $-15.644^{*}$ & -1.462 & $-32.547^{*}$ \\
\hline
\end{tabular}

Note: ${ }^{*}$ and ${ }^{* *}$ denote significance at $1 \%$ and $5 \%$ level, respectively.

Panel-B of table 6 provides the value of stationarity test on futures prices in level form and the first difference of futures prices series. It can be seen that the futures prices of the selected Pharmaceutical companies are found to be non-stationary in the level form, but are stationary in the first difference form with respect to both ADF test and PP test. Highest ADF value for first difference in futures prices series is witnessed for GLAXO Pharma (-16.347), while lowest for Dr. Reddy's (-11.283). Maximum PP value for first difference in futures prices is seen for CIPLA (-33.518) and minimum for Ranbaxy (-25.114).Therefore, we reject the null hypothesis of 'futures price series is stationary in the level form' for the selected six companies in Pharmaceutical sector. Thus, both spot and futures prices on the six selected Pharmaceutical companies are found to be stationary only in the first difference form and not in the level form

\section{Test of Cointegration between Spot and Futures Prices- Analysis and Findings}

The detailed analysis of the long-term relation between spot prices and futures prices of the selected companies are presented below, across the six leading sectors of Indian economy.

\section{Analysis of Test of Cointegration between Spot and Futures Prices for selected companies in Automobile sector}

The results of the Johansen's test of cointegration between spot prices and futures prices for the selected Automobile companies are presented in Table-7. Highest eigen value for the first hypothesis is seen for Hero Honda with 66.378 and lowest for M \& M with 35.642 (significant at 5\% level). Further, the second hypothesis is rejected at 5\% ( not 1\% level) for two other companies namely, Maruti Udyog (39.641) and TVS Motors (38.852).

Testing the two sets of null hypotheses, it is found that only the first null hypothesis is rejected with statistical significance (at $1 \%$ or $5 \%$ ), while the second hypothesis could not be rejected at either $1 \%$ or $5 \%$ level of significance. This implies that only one cointegration equation exists between the spot prices $\left(\mathrm{S}_{t}\right)$ and futures prices $\left(F_{t}\right)$ for all the six Automobile Companies. Tata Motors evidenced the strongest relation between futures and spot prices as seen by the highest value of 0.95 (slope) in the cointegration equation, and weak relation was witnessed for Bajaj Auto (0.85). The constant term is the highest for Hero Honda (11.73) and the lowest for Maruti Udyog ( -8.14). 
Table-7: Results of Johansen's Test of Cointegration for selected companies in Automobile sector

\begin{tabular}{|c|c|c|c|c|c|}
\hline S.No. & Companies & Null Hypothesis & $\begin{array}{l}\text { Alternative } \\
\text { Hypothesis }\end{array}$ & $\begin{array}{c}\text { Eigen Value } \\
\left(\lambda_{\text {Trace }}\right)\end{array}$ & Result \\
\hline & & $\mathrm{r}=0$ & $r>0$ & $46.237^{*}$ & Null Hypothesis is REJECTED \\
\hline \multirow[t]{3}{*}{1} & Bajaj Auto & $r \leq 1$ & $r>1$ & 3.623 & Null Hypothesis is ACCEPTED \\
\hline & & \multicolumn{4}{|c|}{ Cointegration Equation : $\mathrm{S}_{\mathrm{t}}=7.51+0.81 \mathrm{~F}_{\mathrm{t}}$} \\
\hline & & $\mathrm{r}=0$ & $r>0$ & $66.378^{*}$ & Null Hypothesis is REJECTED \\
\hline \multirow[t]{3}{*}{2} & Hero Honda & $r \leq 1$ & $r>1$ & 6.289 & Null Hypothesis is ACCEPTED \\
\hline & & \multicolumn{4}{|c|}{ Cointegration Equation : $S_{t}=11.73+0.94 F_{t}$} \\
\hline & & $\mathrm{r}=0$ & $r>0$ & $39.641^{* *}$ & Null Hypothesis is REJECTED \\
\hline \multirow[t]{3}{*}{3} & Maruti Udyog & $r \leq 1$ & $r>1$ & 3.782 & Null Hypothesis is ACCEPTED \\
\hline & & \multicolumn{4}{|c|}{ Cointegration Equation : $S_{t}=-8.14+0.94 F_{t}$} \\
\hline & & $\mathrm{r}=0$ & $r>0$ & $35.642^{* *}$ & Null Hypothesis is REJECTED \\
\hline \multirow[t]{3}{*}{4} & $M \& M$ & $r \leq 1$ & $r>1$ & 5.397 & Null Hypothesis is ACCEPTED \\
\hline & & \multicolumn{4}{|c|}{ Cointegration Equation : $\mathrm{S}_{\mathrm{t}}=5.27+0.94 \mathrm{~F}_{\mathrm{t}}$} \\
\hline & & $\mathrm{r}=0$ & $r>0$ & $57.896^{*}$ & Null Hypothesis is REJECTED \\
\hline \multirow[t]{3}{*}{5} & Tata Motors & $r \leq 1$ & $r>1$ & 5.682 & Null Hypothesis is ACCEPTED \\
\hline & & \multicolumn{4}{|c|}{ Cointegration Equation : $\mathrm{S}_{\mathrm{t}}=6.38+0.95 \mathrm{~F}_{\mathrm{t}}$} \\
\hline & & $\mathrm{r}=0$ & $r>0$ & $38.852^{* *}$ & Null Hypothesis is REJECTED \\
\hline \multirow[t]{2}{*}{6} & TVS Motors & $r \leq 1$ & $r>1$ & 6.495 & Null Hypothesis is ACCEPTED \\
\hline & & \multicolumn{4}{|c|}{ Cointegration Equation : $S_{t}=-2.74+0.94 F_{t}$} \\
\hline
\end{tabular}

Assumption: Linear deterministic trend in the data;

Note: ${ }^{*}$ denote significance at $1 \%$ and ${ }^{* *}$ denote significance at $5 \%$ level; Testing of Hypothesis done using Likelihood (L.R.) Test; S- spot price, F- futures price, $t$ - time. ' $r$ ' denotes the number of cointegration equations.

\section{Analysis of Test of Cointegration between Spot and Futures Prices for selected companies in Banking sector}

Table 8 provides the results of the Johansen's test of cointegration between spot prices and futures prices for the selected nine banks. Examining the two sets of null hypotheses, it is found that maximum eigen value for the first hypothesis is seen for Bank of Baroda with 83.937and minimum is evidenced for ICICI Bank with Eigen value of 31.658 (significant at 5\% level). It is observed from the eigen values for these banks that only the first null hypothesis is rejected with statistical significance, while the second hypothesis is not rejected at either $1 \%$ or $5 \%$ level of significance.

This implies that only one cointegration equation exists between the spot prices $\left(\mathrm{S}_{\mathrm{t}}\right)$ and futures prices $\left(\mathrm{F}_{\mathrm{t}}\right)$ for all the nine Banks. Further, the first hypothesis is rejected at 5\% (not 1\% level) for two other banks namely, HDFC Bank (36.529) and Union Bank of India (39.628). The second hypothesis cannot be rejected for any of the selected banks. PNB evidenced strongest relation between futures and spot prices as seen by the highest value of slope (0.93) in the single cointegration equation, followed by SBI (0.92). Weak relation between futures and spot prices was witnessed for Oriental Bank (0.78), followed by IDBI (0.84). The constant term was the highest for Bank of Baroda (15.64) followed by SBI (12.44) and the lowest for Canara Bank with value of -9.18 . Two other banks showing negative values for the constant term in the cointegration equation are HDFC Bank (-10.54) and IDBI (-6.51). 
Table-8: Results of Johansen's Test of Cointegration for selected companies in Banking sector

\begin{tabular}{|c|c|c|c|c|c|}
\hline S.No. & Companies & $\begin{array}{c}\text { Null } \\
\text { Hypothesis }\end{array}$ & $\begin{array}{l}\text { Alternative } \\
\text { Hypothesis }\end{array}$ & $\begin{array}{c}\text { Eigen Value } \\
\left(\lambda_{\text {Trace }}\right)\end{array}$ & Result \\
\hline \multirow{3}{*}{1} & \multirow{3}{*}{$\begin{array}{l}\text { Bank } \\
\text { Baroda }\end{array}$} & $\mathrm{r}=0$ & $r>0$ & $83.937^{*}$ & Null Hypothesis is REJECTED \\
\hline & & $r \leq 1$ & $r>1$ & 5.682 & Null Hypothesis is ACCEPTED \\
\hline & & Cointegration & Equation : $S_{t}=$ & $15.64+0.85 \mathrm{~F}_{\mathrm{t}}$ & \\
\hline \multirow{3}{*}{2} & \multirow{3}{*}{ Canara bank } & $\mathrm{r}=0$ & $r>0$ & $75.623^{*}$ & Null Hypothesis is REJECTED \\
\hline & & $r \leq 1$ & $r>1$ & 3.186 & Null Hypothesis is ACCEPTED \\
\hline & & Cointegration & Equation : $S_{t}=$ & $-11.23+0.87 \mathrm{~F}_{\mathrm{t}}$ & \\
\hline \multirow{3}{*}{3} & \multirow{3}{*}{ HDFC Bank } & $\mathrm{r}=0$ & $r>0$ & $36.529^{* *}$ & Null Hypothesis is REJECTED \\
\hline & & $r \leq 1$ & $r>1$ & 5.683 & Null Hypothesis is ACCEPTED \\
\hline & & Cointegration & Equation : $\mathrm{S}_{\mathrm{t}}=$ & $-10.54+0.89 \mathrm{~F}_{\mathrm{t}}$ & \\
\hline \multirow{3}{*}{4} & \multirow{3}{*}{ ICICI Bank } & $r=0$ & $r>0$ & $31.658^{* *}$ & Null Hypothesis is REJECTED \\
\hline & & $r \leq 1$ & $r>1$ & 6.859 & Null Hypothesis is ACCEPTED \\
\hline & & Cointegration & Equation : $S_{t}=$ & $9.72+0.87 \mathrm{~F}_{\mathrm{t}}$ & \\
\hline \multirow{3}{*}{5} & \multirow{3}{*}{ IDBI } & $\mathrm{r}=0$ & $r>0$ & $59.682^{*}$ & Null Hypothesis is REJECTED \\
\hline & & $r \leq 1$ & $r>1$ & 6.374 & Null Hypothesis is ACCEPTED \\
\hline & & Cointegration & Equation : $\mathrm{S}_{\mathrm{t}}=$ & $-6.51+0.84 F_{t}$ & \\
\hline \multirow{3}{*}{6} & \multirow{3}{*}{ Oriental Bank } & $\mathrm{r}=0$ & $r>0$ & $55.689^{*}$ & Null Hypothesis is REJECTED \\
\hline & & $r \leq 1$ & $r>1$ & 4.318 & Null Hypothesis is ACCEPTED \\
\hline & & Cointegration & Equation : $S_{t}=$ & $11.41+0.78 \mathrm{~F}_{\mathrm{t}}$ & \\
\hline \multirow{3}{*}{7} & \multirow{3}{*}{ PNB } & $\mathrm{r}=0$ & $r>0$ & $64.538^{*}$ & Null Hypothesis is REJECTED \\
\hline & & $r \leq 1$ & $r>1$ & 3.592 & Null Hypothesis is ACCEPTED \\
\hline & & Cointegration & Equation : $S_{t}=$ & $5.61+0.93 \mathrm{~F}_{\mathrm{t}}$ & \\
\hline \multirow{3}{*}{8} & \multirow{3}{*}{ SBI } & $\mathrm{r}=0$ & $r>0$ & $55.683^{*}$ & Null Hypothesis is REJECTED \\
\hline & & $r \leq 1$ & $r>1$ & 6.589 & Null Hypothesis is ACCEPTED \\
\hline & & Cointegration & Equation : $S_{t}=$ & $12.44+0.92 \mathrm{~F}_{\mathrm{t}}$ & \\
\hline \multirow{3}{*}{9} & \multirow{3}{*}{$\begin{array}{l}\text { Union Bank of } \\
\text { India }\end{array}$} & $r=0$ & $r>0$ & $39.628^{* *}$ & Null Hypothesis is REJECTED \\
\hline & & $r \leq 1$ & $r>1$ & 4.369 & Null Hypothesis is ACCEPTED \\
\hline & & Cointegration & Equation : $S_{t}=$ & $6.68+0.91 \mathrm{~F}_{\mathrm{t}}$ & \\
\hline
\end{tabular}

Assumption: Linear deterministic trend in the data;

Note: ${ }^{*}$ denote significance at $1 \%$ and ${ }^{* *}$ denote significance at $5 \%$ level; Testing of Hypothesis done using Likelihood (L.R.) Test; S- spot price, F- futures price, $t$ - time. ' $r$ ' denotes the number of cointegration equations.

\section{Analysis of Test of Cointegration between Spot and Futures Prices for selected companies in Cement sector}

The results of the Johansen's test of cointegration between spot prices and futures prices for the selected Cement companies are presented in table 9. Highest eigen value for the first hypothesis is seen for ACC with 49.247and minimum for Grasim Cements with 30.462 (significant at 5\% level). Further, the first hypothesis is rejected at 5\% (not 1\% level) for two other companies namely, Gujrat Ambuja Cements and India Cements with eigen values of 32.591 and 35.846, respectively. Testing the two sets of null hypotheses, it is found that only the first null hypothesis is rejected with statistical significance either at $1 \%$ or $5 \%$, while the second 
hypothesis could not be rejected at either $1 \%$ or $5 \%$ level of significance. This implies that only one cointegration equation exists between the spot prices $\left(\mathrm{S}_{t}\right)$ and futures prices $\left(\mathrm{F}_{t}\right)$ for all the four selected Cement companies. Gujrat Ambuja Cements evidenced strongest relation between futures and spot prices as seen by the highest value of 0.97 (slope) in the cointegration equation, and weak relation was witnessed for ACC (0.83). The constant term was the highest for Grasim Cements (12.79) and the lowest for India Cements with value of -4.26 .

Table-9: Results of Johansen's Test of Cointegration for selected companies in Cement sector

\begin{tabular}{|c|c|c|c|c|c|}
\hline S.No. & Companies & $\begin{array}{c}\text { Null } \\
\text { Hypothesis }\end{array}$ & $\begin{array}{l}\text { Alternative } \\
\text { Hypothesis }\end{array}$ & $\begin{array}{c}\text { Eigen Value } \\
\left(\lambda_{\text {Trace })}\right.\end{array}$ & Result \\
\hline \multirow{3}{*}{1} & \multirow{3}{*}{ ACC } & $\mathrm{r}=0$ & $r>0$ & $49.247^{*}$ & Null Hypothesis is REJECTED \\
\hline & & $r \leq 1$ & $r>1$ & 2.385 & Null Hypothesis is ACCEPTED \\
\hline & & \multicolumn{4}{|c|}{ Cointegration Equation: $S_{t}=5.88+0.83 F_{t}$} \\
\hline \multirow{3}{*}{2} & \multirow{3}{*}{$\begin{array}{l}\text { Grasim } \\
\text { Cements }\end{array}$} & $\mathrm{r}=0$ & $r>0$ & $30.462^{* *}$ & Null Hypothesis is REJECTED \\
\hline & & $r \leq 1$ & $r>1$ & 3.684 & Null Hypothesis is ACCEPTED \\
\hline & & Cointegratio & Equation : $S_{t}$ & $12.79+0.86 \mathrm{~F}$ & \\
\hline \multirow{3}{*}{3} & \multirow{3}{*}{$\begin{array}{l}\text { Gujrat Ambuja } \\
\text { Cements }\end{array}$} & $\mathrm{r}=0$ & $r>0$ & $32.591^{* *}$ & Null Hypothesis is REJECTED \\
\hline & & $r \leq 1$ & $r>1$ & 3.689 & Null Hypothesis is ACCEPTED \\
\hline & & Cointegratio & Equation : $S_{t}$ & $10.52+0.97 \mathrm{~F}$ & \\
\hline \multirow{3}{*}{4} & & $r=0$ & $r>0$ & $35.846^{* *}$ & Null Hypothesis is REJECTED \\
\hline & India Cements & $r \leq 1$ & $r>1$ & 6.386 & Null Hypothesis is ACCEPTED \\
\hline & & \multicolumn{4}{|c|}{ Cointegration Equation : $\mathrm{S}_{\mathrm{t}}=-4.26+0.89 \mathrm{~F}_{\mathrm{t}}$} \\
\hline
\end{tabular}

Assumption: Linear deterministic trend in the data;

Note: ${ }^{*}$ denote significance at $1 \%$ and ${ }^{* *}$ denote significance at $5 \%$ level; Testing of Hypothesis done using Likelihood (L.R.) Test; S- spot price, F- futures price, $t$ - time. ' $r$ ' denotes the number of cointegration equations.

\section{Analysis of Test of Cointegration between Spot and Futures Prices for selected companies in Gas, Oil \& Refineries sector}

The table 10 provides the results of the Johansen's test of cointegration between spot prices and futures prices for the selected eight companies in the Gas, Oil \& Refineries sector. Two sets of null hypotheses are tested to find out the number of cointegration relationship between the spot and futures prices series. Maximum eigen value for the first hypothesis is seen for Reliance Industries (67.594), followed by GAIL (65.329) and BPCL (56.325). Minimum eigen values for first hypothesis was witnessed for IOC (32.659) followed by IPCL (33.965) and HPCL (46.398), all the three being significant at 5\% level. It is observed from the eigen values for the selected companies that only the first null hypothesis is rejected with statistical significance, while the second hypothesis is not rejected at either $1 \%$ or $5 \%$ level of significance.

This implies that only one cointegration equation exists between the spot prices $\left(\mathrm{S}_{\mathrm{t}}\right)$ and futures prices $\left(\mathrm{F}_{\mathrm{t}}\right)$ for all the eight Companies in the Gas, Oil \& Refineries sector. Further, the second hypothesis could not be rejected for any of the selected companies. Bongaigaon Refineries evidenced strongest relation between futures and spot prices as seen by the highest value of slope (0.94) of the cointegration equation, followed by IPCL (0.91) and HPCL (0.87). Weakest relation between futures and spot prices was witnessed for BPCL (0.77), followed by IOC (0.80) and Reliance Industries (0.81). The constant term is the highest for ONGC (11.26) and the lowest for GAIL with value of -8.26. Two other companies showing negative values for the constant term in the cointegration equation are HPCL (-4.94) and BPCL (-5.24). 
Table-10: Results of Johansen's Cointegration for companies in Gas, Oil \& Refineries

\begin{tabular}{|c|c|c|c|c|c|}
\hline S.No. & Companies & $\begin{array}{c}\text { Null } \\
\text { Hypothesis }\end{array}$ & $\begin{array}{l}\text { Alternative } \\
\text { Hypothesis }\end{array}$ & $\begin{array}{c}\text { Eigen Value } \\
\left(\lambda_{\text {Trace })}\right.\end{array}$ & Result \\
\hline \multirow{3}{*}{1} & \multirow{3}{*}{ BPCL } & $\mathrm{r}=0$ & $r>0$ & $56.325^{*}$ & Null Hypothesis is REJECTED \\
\hline & & $r \leq 1$ & $r>1$ & 5.396 & Null Hypothesis is ACCEPTED \\
\hline & & Cointegration & Equation : $\mathrm{S}_{\mathrm{t}}=$ & $5.24+0.77 \mathrm{~F}_{\mathrm{t}}$ & \\
\hline \multirow{3}{*}{2} & \multirow{3}{*}{$\begin{array}{l}\text { Bongaigaon } \\
\text { Refineries }\end{array}$} & $\mathrm{r}=0$ & $r>0$ & $52.329 *$ & Null Hypothesis is REJECTED \\
\hline & & $r \leq 1$ & $r>1$ & 3.658 & Null Hypothesis is ACCEPTED \\
\hline & & Cointegration & Equation : $S_{t}=$ & $10.51+0.94 \mathrm{~F}_{\mathrm{t}}$ & \\
\hline \multirow{3}{*}{3} & \multirow{3}{*}{ GAIL } & $\mathrm{r}=0$ & $r>0$ & $65.329 *$ & Null Hypothesis is REJECTED \\
\hline & & $r \leq 1$ & $r>1$ & 4.683 & Null Hypothesis is ACCEPTED \\
\hline & & Cointegration & Equation : $S_{t}=$ & $-8.26+0.81 F_{t}$ & \\
\hline \multirow{3}{*}{4} & \multirow{3}{*}{ HPCL } & $\mathrm{r}=0$ & $r>0$ & $46.398^{*}$ & Null Hypothesis is REJECTED \\
\hline & & $r \leq 1$ & $r>1$ & 2.396 & Null Hypothesis is ACCEPTED \\
\hline & & Cointegration & Equation : $\mathrm{S}_{\mathrm{t}}=$ & $4.94+0.87 \mathrm{~F}_{\mathrm{t}}$ & \\
\hline \multirow{3}{*}{5} & \multirow{3}{*}{ IOC } & $\mathrm{r}=0$ & $r>0$ & $32.659^{* *}$ & Null Hypothesis is REJECTED \\
\hline & & $r \leq 1$ & $r>1$ & 4.682 & Null Hypothesis is ACCEPTED \\
\hline & & Cointegration & Equation : $\mathrm{S}_{\mathrm{t}}=$ & $9.24+0.80 F_{t}$ & \\
\hline \multirow{3}{*}{6} & \multirow{3}{*}{ IPCL } & $\mathrm{r}=0$ & $r>0$ & $33.965^{* *}$ & Null Hypothesis is REJECTED \\
\hline & & $r \leq 1$ & $r>1$ & 6.761 & Null Hypothesis is ACCEPTED \\
\hline & & Cointegration & Equation : $\mathrm{S}_{\mathrm{t}}=$ & $7.66+0.91 \mathrm{~F}_{\mathrm{t}}$ & \\
\hline \multirow{3}{*}{7} & \multirow{3}{*}{ ONGC } & $\mathrm{r}=0$ & $r>0$ & $49.653^{*}$ & Null Hypothesis is REJECTED \\
\hline & & $r \leq 1$ & $r>1$ & 3.695 & Null Hypothesis is ACCEPTED \\
\hline & & Cointegration & Equation : $\mathrm{S}_{\mathrm{t}}=$ & $11.26+0.81 \mathrm{~F}_{\mathrm{t}}$ & \\
\hline \multirow{3}{*}{8} & \multirow{3}{*}{$\begin{array}{l}\text { Reliance } \\
\text { Industries }\end{array}$} & $\mathrm{r}=0$ & $r>0$ & $67.594^{*}$ & Null Hypothesis is REJECTED \\
\hline & & $r \leq 1$ & $r>1$ & 4.569 & Null Hypothesis is ACCEPTED \\
\hline & & Cointegration & Equation : $\mathrm{S}_{\mathrm{t}}=$ & $5.75+0.81 \mathrm{~F}_{\mathrm{t}}$ & \\
\hline
\end{tabular}

Assumption: Linear deterministic trend in the data;

Note: ${ }^{*}$ denote significance at $1 \%$ and ${ }^{* *}$ denote significance at $5 \%$ level; Testing of Hypothesis done using Likelihood (L.R.) Test; S- spot price, F- futures price, $t$ - time. ' $r$ ' denotes the number of cointegration equations.

\section{Analysis of Test of Cointegration between Spot and Futures Prices for selected companies in Information Technology (IT) sector}

The results of the Johansen's test of cointegration between spot prices and futures prices for the selected IT companies are presented in table 11. Highest Eigen value for the first hypothesis is seen for Polaris (71.526), followed by Satyam Computers (66.329).Minimum Eigen value for first hypothesis is found in case of Infosys Tech (40.236) followed by WIPRO (57.961), all being found to be significant at $1 \%$ level. Testing the two sets of null hypotheses, it is found that only the first null hypothesis is rejected with statistical significance, while the second hypothesis could not be rejected at either $1 \%$ or $5 \%$ level of significance. This implies that only one cointegration equation exists between the spot prices $\left(\mathrm{S}_{t}\right)$ and futures prices $\left(\mathrm{F}_{t}\right)$ for all the seven IT companies. 


\begin{tabular}{|c|c|c|c|c|c|}
\hline S.No. & Indices & $\begin{array}{c}\text { Null } \\
\text { Hypothesis }\end{array}$ & $\begin{array}{l}\text { Alternative } \\
\text { Hypothesis }\end{array}$ & $\begin{array}{l}\text { Eigen } \\
\text { Value } \\
\left(\lambda_{\text {Trace })}\right.\end{array}$ & Result \\
\hline \multirow[t]{3}{*}{1} & I-Flex & $\mathrm{r}=0$ & $r>0$ & $59.527^{*}$ & Null Hypothesis is REJECTED \\
\hline & & $r \leq 1$ & $r>1$ & 6.329 & Null Hypothesis is ACCEPTED \\
\hline & & \multicolumn{4}{|c|}{ Cointegration Equation : $S_{t}=-7.54+0.97 F_{t}$} \\
\hline \multirow[t]{3}{*}{2} & Infosys Tech & $\mathrm{r}=0$ & $r>0$ & $40.236^{*}$ & Null Hypothesis is REJECTED \\
\hline & & $r \leq 1$ & $r>1$ & 6.264 & Null Hypothesis is ACCEPTED \\
\hline & & \multicolumn{4}{|c|}{ Cointegration Equation : $\mathrm{S}_{\mathrm{t}}=8.56+0.79 \mathrm{~F}_{\mathrm{t}}$} \\
\hline \multirow[t]{3}{*}{3} & Patni & $\mathrm{r}=0$ & $r>0$ & $64.329 *$ & Null Hypothesis is REJECTED \\
\hline & Computers & $r \leq 1$ & $r>1$ & 2.395 & Null Hypothesis is ACCEPTED \\
\hline & & \multicolumn{4}{|c|}{ Cointegration Equation : $\mathrm{S}_{\mathrm{t}}=-12.42+0.91 \mathrm{~F}_{\mathrm{t}}$} \\
\hline \multirow[t]{3}{*}{4} & Polaris & $\mathrm{r}=0$ & $r>0$ & $71.526^{*}$ & Null Hypothesis is REJECTED \\
\hline & & $r \leq 1$ & $r>1$ & 4.759 & Null Hypothesis is ACCEPTED \\
\hline & & \multicolumn{4}{|c|}{ Cointegration Equation : $\mathrm{S}_{\mathrm{t}}=6.41+0.76 \mathrm{~F}_{\mathrm{t}}$} \\
\hline \multirow[t]{3}{*}{5} & Satyam & $r=0$ & $r>0$ & $66.329 *$ & Null Hypothesis is REJECTED \\
\hline & Computers & $r \leq 1$ & $r>1$ & 4.238 & Null Hypothesis is ACCEPTED \\
\hline & & \multicolumn{4}{|c|}{ Cointegration Equation : $S_{t}=14.68+0.84 F_{t}$} \\
\hline \multirow[t]{3}{*}{6} & TCS & $\mathrm{r}=0$ & $r>0$ & $60.385^{*}$ & Null Hypothesis is REJECTED \\
\hline & & $r \leq 1$ & $r>1$ & 3.310 & Null Hypothesis is ACCEPTED \\
\hline & & \multicolumn{4}{|c|}{ Cointegration Equation : $S_{t}=10.49+0.89 F_{t}$} \\
\hline \multirow[t]{3}{*}{7} & WIPRO & $r=0$ & $r>0$ & $57.961^{*}$ & Null Hypothesis is REJECTED \\
\hline & & $r \leq 1$ & $r>1$ & 5.686 & Null Hypothesis is ACCEPTED \\
\hline & & \multicolumn{4}{|c|}{ Cointegration Equation : $S_{t}=-9.71+0.82 F_{t}$} \\
\hline
\end{tabular}

Assumption: Linear deterministic trend in the data;

Note: ${ }^{*}$ denote significance at $1 \%$ and ${ }^{* *}$ denote significance at $5 \%$ level; Testing of Hypothesis done using Likelihood (L.R.) Test; S- spot price, F- futures price, $t$ - time. ' $r$ ' denotes the number of cointegration equations.

The I-Flex evidenced strongest relation between futures and spot prices as seen by the highest value of slope (0.97) of the cointegration equation, followed by Patni Computers (0.93) and TCS (0.89). Weakest relationship between spot prices and futures prices was witnessed for Polaris (0.76), followed by Infosys Tech (0.79) and WIPRO (0.82). The constant term was highest for Satyam Computers (14.68) and lowest for Patni Computers with negative value of -12.42 . Two other companies showing negative values for the constant term in the cointegration equation are WIPRO (-9.7 1) and I-Flex (- 7.54).

\section{Analysis of Test of Cointegration between Spot and Futures Prices for selected companies in Pharmaceutical sector}

Table-12 provides the results of the Johansen's test of cointegration between spot prices and futures prices for the selected six Pharmaceutical companies. Two sets of null hypotheses are tested to find out the number of cointegration relations between the spot and futures price series. Highest Eigen value for the first hypothesis is seen for Dr. Reddy's (87.263) , followed by Ranbaxy (76.528) and Wockhardt (55.648). Lowest Eigen value for first hypothesis was witnessed for DABUR with value of 35.628 (significant at 5\% level) followed by GLAXO Pharma (38.694) and CIPLA (43.156), all the others being significant at 1\% level. Further, it is observed from the Eigen values for the selected companies that only the first null hypothesis is rejected with statistical significance, while the second hypothesis could not be rejected at either $1 \%$ or $5 \%$ level of significance. This indicates that only one cointegration equation exists between the spot prices $\left(\mathrm{S}_{\mathrm{t}}\right)$ and futures prices $\left(\mathrm{F}_{\mathrm{t}}\right)$ for all the six companies in the Pharmaceutical sector. 
Table-12: Results of Johansen's Test of Cointegration for selected companies in Pharmaceutical sector

\begin{tabular}{|c|c|c|c|c|c|}
\hline S.No. & Companies & $\begin{array}{c}\text { Null } \\
\text { Hypothesis }\end{array}$ & $\begin{array}{l}\text { Alternative } \\
\text { Hypothesis }\end{array}$ & $\begin{array}{l}\text { Eigen } \\
\text { Value } \\
\left(\lambda_{\text {Trace })}\right. \\
\end{array}$ & Result \\
\hline \multirow{3}{*}{1} & \multirow{3}{*}{ CIPLA } & $\mathrm{r}=0$ & $r>0$ & $43.156^{*}$ & Null Hypothesis is REJECTED \\
\hline & & $r \leq 1$ & $r>1$ & 5.692 & Null Hypothesis is ACCEPTED \\
\hline & & Cointegration & quation : $S_{t}=-$ & $1.23+0.86 \mathrm{~F}_{\mathrm{t}}$ & \\
\hline \multirow{3}{*}{2} & \multirow{3}{*}{ Dr. Reddy's } & $r=0$ & $r>0$ & $87.263^{*}$ & Null Hypothesis is REJECTED \\
\hline & & $r \leq 1$ & $r>1$ & 5.896 & Null Hypothesis is ACCEPTED \\
\hline & & Cointegration & quation : $S_{t}=9$ & $46+0.82 \mathrm{~F}_{\mathrm{t}}$ & \\
\hline \multirow[t]{2}{*}{3} & \multirow{2}{*}{ DABUR } & $r \leq 1$ & $r>1$ & 5.629 & Null Hypothesis is ACCEPTED \\
\hline & & Cointegration & quation : $S_{t}=-$ & $3.55+0.74 \mathrm{~F}_{\mathrm{t}}$ & \\
\hline \multirow[t]{2}{*}{4} & \multirow{2}{*}{$\begin{array}{l}\text { GLAXO } \\
\text { Pharma }\end{array}$} & & $\begin{array}{l}r>0 \\
r>1\end{array}$ & $\begin{array}{l}38.694^{*} \\
3.647\end{array}$ & $\begin{array}{l}\text { Null Hypothesis is REJECTED } \\
\text { Null Hypothesis is ACCEPTED }\end{array}$ \\
\hline & & Cointegration & quation : $S_{t}=5$ & $79+0.89 \mathrm{~F}_{\mathrm{t}}$ & \\
\hline \multirow[b]{2}{*}{5} & \multirow[b]{2}{*}{ Ranbaxy } & $r=0$ & $r>0$ & 76.528* & Null Hypothesis is REJECTED \\
\hline & & $r \leq 1$ & $r>1$ & 6.194 & Null Hypothesis is ACCEPTED \\
\hline \multirow{2}{*}{6} & \multirow{2}{*}{ Wockhardt } & $\begin{array}{l}\text { Cointegration } \\
r=0 \\
r \leq 1\end{array}$ & $\begin{array}{l}\text { quation: } S_{t}=1 \\
\quad r>0 \\
r>1\end{array}$ & $\begin{array}{l}2.38+0.79 \mathrm{~F}_{\mathrm{t}} \\
55.648^{*} \\
2.392\end{array}$ & $\begin{array}{l}\text { Null Hypothesis is REJECTED } \\
\text { Null Hypothesis is ACCEPTED }\end{array}$ \\
\hline & & Cointegration & quation : $S_{t}=\varepsilon$ & $29+0.72 \mathrm{~F}_{\mathrm{t}}$ & 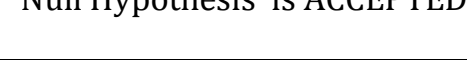 \\
\hline
\end{tabular}

Assumption: Linear deterministic trend in the data;

Note: * denote significance at $1 \%$ and ${ }^{* *}$ denote significance at $5 \%$ level; Testing of Hypothesis done using

Likelihood (L.R.) Test; S- spot price, F-futures price, t- time. ' $r$ ' denotes the number of cointegration

equations.

Further, the second hypothesis could not be rejected for any of the selected Pharmaceutical companies. GLAXO Pharma evidenced strongest relation between futures and spot prices as seen by the highest value of slope (0.89) in the cointegration equation, followed by CIPLA (0.86) and Dr. Reddy's (0.82).The cointegration equations shows that weakest relationship between futures and spot prices was witnessed for Wockhardt (0.72), followed by DABUR (0.74) and Ranbaxy (0.79). The constant term in the cointegration equations was found to be highest for Ranbaxy (12.38) followed by Dr. Reddy's (9.46), whereas lowest value for the constant term was seen for DABUR (-13.55) followed by CIPLA(-11.23).

\section{Conclusion}

The study first examined the stationarity for spot prices and futures prices using two econometric methods namely, Philips Perron (PP) test and Augmented Dickey-Fuller (ADF) test. It is found that both spot prices and futures prices for the selected companies are not stationary in the level form, but there is evidence of stationarity in the first difference form. This leads the study towards applying the test of cointegration to examine the long term relation between spot and futures prices. The study attempts to examine whether the spot market and futures market under consideration move in the same direction in the long run or not. Johansen's cointegration test is utilized for this purpose. For all the six Automobile companies, a single cointegration (long-term) relationship exists between the spot prices and futures prices. Further, Tata Motors is found to have strongest relation between futures and spot prices and Bajaj Auto has the weakest relation. The Johansen's test of cointegration between spot prices and futures prices for the selected nine banks reveals for each bank. PNB evidenced strongest relation between futures and spot prices, and Oriental Bank is found to have the weakest relationship.

In the Cement sector, the single cointegration equation between the spot and futures prices for each of the four Cement companies indicate that both spot and futures prices are stationary in the first difference form. Gujrat Ambuja Cements evidences strongest relation between futures and spot prices, and ACC is found to have the weakest relationship. Each of the eight companies in the Gas, Oil \& Refineries sector also evidence 
single cointegration relation between spot and futures prices, significant at $1 \%$ or $5 \%$ level. Bongaigaon Refineries is observed to evidence strongest relation between futures and spot prices, with weakest relation for BPCL. Among the seven selected IT companies, I-Flex showed strongest relation between futures and spot prices, with weakest relation for Polaris. Although each of the six selected Pharmaceutical companies showed single cointegration relation between spot and futures prices, GLAXO Pharma is found to have strongest relation and Wockhardt is found to have the weakest relationship between spot and futures prices.

The findings of the study are relevant to investors and academicians who wish to study the inter-relationship between the movement in spot price and futures price. With the onset of derivative trading, there has been existence of better price discovery mechanism through an in-depth study on spot and their co-movement with futures prices.

\section{Limitations of the study}

The major limitations of the study are;

1. This study has employed daily price series for both spot and futures market. Intra-day minute-tominute prices were not readily available for analysis.

2. Since the futures trading on individual stocks and indices listed in NSE commenced after year 2000, the futures price data used in the study has been taken from this year onwards.

3. Although spot data was available for the study period, futures data was not completely available for the entire study because of difference in commencement data of futures trading for the selected stocks.

\section{References}

Brooks, C. Rew, A. G. and Ritson, S. (2001): A trading strategy based on the lead-lag relationship between the spot index and futures contract for the FTSE 100, International Journal of Forecasting, 171:31-44.

Chan, K. (1992). A Further Analysis of the Lead-Lag Relationship between the Cash Market and Stock Index Futures Market. The Review of Financial Studies, 5(1): 123-152.

Frino, A. and West, A. (2002), 'The Lead-Lag Relationship between Stock Indices and Stock Index Futures Contracts: Further Australian Evidence', Journal of Accounting, Finance and Business Studies, Wiley Interscience, 35(3): 333-341.

Ghosh, A. (1993), 'Cointegration and error correction models: Inter temporal causality between index and future price', The Journal of Future markets, 2: 193-198.

Johansen, S. and Juselius, K. (1990), 'Maximum likelihood estimation and inference on cointegration with application to the demand for money', Oxford Bulletin of Economics and Statistics, 22: 181-211.

Kawaller, I. G., Koch, P. D. and Koch, T. W. (1987), 'The Temporal Price Relationship between S\&P 500 Futures and the S\&P 500 Index', Journal of Finance, 26(5): 1309-1329.

Lai, K. S. and Lai, M. (1991), 'A Cointegration Test for Market Efficiency', The Journal of Futures Markets, 11: 567-575.

Pati, P. C. and Kumar, K. K. (2007), 'Maturity and Volume Effects on the Volatility: Evidences from NSE Nifty Futures', ICFAI Journal of Derivatives Markets, 4(4): 44-63.

Praveen, D. G. and Sudhakar, A. (2006), 'Price Discovery and Causality in the Indian Derivatives Market', ICFAI Journal of Derivatives Markets, 3(1): 22-29.

Reddy, Y. V. and Sebastin, A. (2008), 'Interaction between Equity and Derivatives Markets in India: An Entropy Approach', ICFAI Journal of Derivatives Markets, 5(1): 18-32.

Sah, A. N. and Omkarnath, G. (2005), 'Causal Relationship Between Futures Contracts and Volatility of the Spot Market: A Case of S\&P CNX Nifty and Nifty Futures', ICFAI Journal of Derivatives Markets, 2(2): 64-71.

Schwarz, T. V. and Laatsch, F. (1991), 'Dynamic Efficiency and Price Leadership in Stock Index Cash and Futures Markets', The Journal of Futures Markets, 11: 669-683.

Teppo, M., Jukka, P., and Vesa, P. (1995), "On the dynamics of stock index futures and individual stock returns", Journal of Business Finance and Accounting, 2(1): 87-100. 